\title{
KEMAL ATATURK DAN PEMBAHARUAN DI TURKI: POLEMIK DALAM AKHBAR DAN MAJALAH MELAYU PADA TAHUN 1920-AN DAN 1930-AN
}

\author{
Abu Hanifah Haris \\ Mohammad Redzuan Othman
}

\begin{abstract}
The rise of Kemal Ataturk (1881-1938) as President of the Republic of Turkey in 1924 resulted in him being regarded as a highly respected political leader among the Malays. This is clear from the extensive coverage on him given by Malay newspapers and magazines. This article will focus on the polemics evident in the Malay newspapers and magazines of the period revolving around Kemal's modernisation plans. In the early stages, most of the Malay newspapers and magazines supported Kemal's establishment of the Republic of Turkey and his modernisation programmes. However, support for Kemal's modernisation plans reduced considerably when it became obvious that the modernisation programmes began to marginalize Islam and the elements of secularism became clear. Several controversial issues related to the modernisation programmes that were clearly against Islamic teachings eventually gave rise to polemical discussions in the Malay newspapers and journals.
\end{abstract}

\section{Pengenalan}

Akhbar dan majalah merupakan gambaran dan pandangan sesebuah masyarakat berkenaan pelbagai peristiwa dan fenomena yang berlaku dalam masyarakatnya. Peristiwa dan fenomena tersebut kemudian telah digambarkan oleh penulis akhbar dan majalah yang peka 
terhadap peristiwa yang sedang berlaku dalam masyarakatnya melalui tulisan mereka sama ada dalam bentuk berita atau rencana. Tulisan yang disiarkan sering menggambarkan kesedaran penulis tentang nasib dan hak masyarakatnya yang diterjemahkan melalui pelbagai kritikan, cadangan dan saranan yang dilontarkan untuk memperbaiki kekurangan dan kelemahan yang sedang melanda masyarakatnya. Akhbar dan majalah ini kemudiannya menjadi medan bagi para penulis untuk bertukar-tukar pendapat dan pandangan berkenaan sesuatu isu khususnya isu yang mempunyai impak yang besar dalam sesebuah masyarakat seperti isu agama, politik dan pemerintahan, adat dan kebudayaan, pendidikan dan ekonomi. Melalui tulisan-tulisan ini, pelbagai perbincangan dan diskusi dapat diadakan dalam kalangan mereka yang mempunyai buah fikiran, pandangan dan penelitian yang lebih tajam berkenaan pelbagai peristiwa dan fenomena yang berlaku dalam kalangan orang Melayu.

Pada dekad ketiga abad ke-20, kegiatan persuratkhabaran dan permajalahan Melayu telah mengalami perkembangan yang begitu pesat di Tanah Melayu. Kadar celik huruf orang Melayu yang semakin meningkatkan hasil kemajuan yang dicapai dalam bidang pendidikan dalam kalangan orang Melayu menyaksikan permintaan dan sambutan terhadap media cetak khususnya akhbar dan majalah Melayu semakin meningkat. Pelbagai akhbar dan majalah Melayu muncul silih berganti dalam usaha menyampaikan pelbagai isu dan berita yang berlaku di Tanah Melayu dan seluruh dunia khususnya peristiwa yang berlaku di Timur Tengah. Antara peristiwa di Timur Tengah yang begitu menarik perhatian orang Melayu sekitar tahun 1920-an adalah rancangan pembangunan dan pemodenan Turki yang dilancarkan oleh presiden pertama Republik Turki iaitu Kemal Ataturk (1881-1938). Perkembangan yang berlaku di Turki mendedahkan orang Melayu kepada pelbagai polemik yang terhasil akibat proses pemodenan dan pensekularan yang dilaksanakan oleh Kemal sejak menerajui pemerintahan Turki. Bagi orang Melayu, peristiwa yang terjadi di Turki itu boleh dijadikan pengajaran dan tauladan dalam usaha membangunkan orang Melayu ke arah kemajuan dalam segenap aspek. Perkembangan yang sedang rancak berlaku di Turki telah menarik minat beberapa akhbar dan majalah Melayu seperti Pengasoh, Al-Ikhwan, Malaya, Majalah Guru, Al-Hedayah, Bahtra dan Saudara yang meraikan kejayaan Kemal menubuhkan Republik Turki serta pelbagai rancangan pemodenan yang telah dijalankan bagi membangunkan Turki menjadi sebuah negara moden. Jelaslah di sini bahawa peristiwa kenaikan Kemal dan rancangan pemodenan yang dijalankan begitu popular dalam akhbar dan majalah. Melayu pada tahun 1920-an. 


\section{Kenaikan Kemal Dan Rancangan Pemodenan Turki}

Kemal Ataturk (1881-1938) merupakan seorang pegawai tentera dan presiden Turki yang terkenal. Meskipun dilahirkan sebagai anak seorang petani sahaja, beliau akhirnya berjaya memasuki sekolah tentera seterusnya muncul sebagai salah seorang pegawai tentera Turki yang berjaya. ${ }^{1}$ Beliau dianggap seorang pemimpin yang memiliki karisma dalam mencorakkan masa depan Turki daripada sebuah empayar kepada sebuah republik. ${ }^{2}$ Pada awal abad ke-20, Turki telah terlibat dalam kancah Perang Dunia Pertama. Kemasukan Daulah Uthmaniyah dalam peperangan tersebut dengan memihak kepada Jerman dalam pakatan The Central Powers pada bulan Oktober 1914 menentang British, Perancis dan Rusia dalam pakatan The Entente Powers telah membuka lembaran baru dalam sejarah Dunia Islam. ${ }^{3}$ Sebelum itu, Turki telah menandatangani perjanjian sulit dengan Jerman pada 2 Ogos $1914 .{ }^{4}$ Hasil perjanjian tersebut, ramai tentera Jerman telah dibawa masuk ke dalam Turki menggunakan keretapi bagi membantu persiapan tentera Turki untuk menentang pihak musuh. ${ }^{5}$ Pada 5 Ogos 1914, pihak British telah mengumumkan secara rasmi berkenaan peperangan antara British dengan Turki. ${ }^{6}$

Dalam Perang Dunia Pertama, Kemal yang ketika itu memegang jawatan Leftenan Kolonel telah ditugaskan oleh Mahmud Shaukat Pasha untuk memimpin tentera Turki dalam Perang Gallipoli (19151916). ${ }^{7}$ Meskipun Turki mengalami kekalahan dan mengakibatkan kehilangan hampir tiga juta nyawa, ${ }^{8}$ namun Kemal berjaya memimpin tentera Turki mengalahkan Greece di Gallipoli, sekaligus berjaya mengelakkan Istanbul daripada penguasaan British. Keberanian dan strategi ketenteraan beliau yang bijaksana telah mengangkat kedudukan Kemal sebagai hero atas kemenangan hebat Turki di dalam peperangan tersebut. ${ }^{9}$ Kemenangan tersebut juga menyebabkan Kemal digelar oleh akhbar Turki sebagai 'The Saviour of Gallipoli'. ${ }^{10}$ Hasi] kerjasama dengan beberapa pemimpin Turki yang lain, Kemal telah memimpin Pertubuhan Kebangsaan Turki dalam Perang Kemerdekaan Turki. Beliau kemudiannya terlibat secara langsung dalam penubuhan Republik Turki seterusnya dilantik menjadi Presiden Turki yang pertama pada tahun 1923.11

Sejak penukaran ibu negara Turki dari Istanbul ${ }^{12}$ ke Ankara pada 13 Oktober $1923^{13}$ seterusnya penubuhan Republik Turki pada 29 Oktober $1923,{ }^{14}$ Kemal telah menjalankan pelbagai rancangan pembaratan berdasarkan prinsip sekularisme.$^{15}$ Reformasi Kemal ini dilancarkan bertujuan untuk mencapai beberapa matlamat dan tujuan seperti menguatkan lagi kuasa dalam pentadbiran pusat yang baru, membina negara bangsa, mensekularkan negara dan masyarakat 
Turki, merealisasikan penglibatan politik selain membawa perubahan dalam struktur sosio-ekonomi Turki. ${ }^{16}$ Kemal juga telah terlibat dalam penggubalan beberapa undang-undang baru seperti undang-undang penyatuan pendidikan sekular (3 Mac 1924), undang-undang pemakaian topi (25 November 1925), undang-undang pengharaman tarikat, penutupan pusat kegiatan tarikat, penutupan makam wali dan penghapusan jawatan penjaga makam wali (30 November 1925), undang-undang perkahwinan sivil (17 Februari 1926), undang-undang penggunaan angka antarabangsa (20 Mei 1828), undang-undang penggunaan huruf Latin bagi tulisan Turki (1 November 1928), undang-undang pengharaman gelaran dan pangkat yang digunakan oleh rakyat Turki seperti Efendi, Bey dan Pasha (26 November 1934) dan undang-undang larangan pemakaian mengikut cara Islam (3 Disember 1934). ${ }^{17}$

Kemal juga telah memberikan hak berpolitik kepada wanita selain memberikan pelbagai kebebasan lain sebagai wanita moden. ${ }^{18}$ Selain itu, beliau bertindak menukarkan kalendar Islam kepada kalendar Gregorian (1925), memperkenalkan sistem angka Eropah (1928), mewujudkan nama keluarga (1934) dan menukarkan cuti hujung minggu dari hari Jumaat kepada hari Ahad (1935). ${ }^{19}$ Beliau juga bertindak menukar lafaz azan daripada bahasa Arab kepada bahasa Turki, memansuhkan sekolah agama, menggugurkan mahkamah syariah, memperkenalkan undang-undang sivil Switzerland, ${ }^{21}$ undangundang jenayah Jerman dan kod ekonomi Itali serta menggugurkan Islam sebagai agama rasmi dan digantikan dengan pengisytiharan Turki sebagai sebuah negara sekular. ${ }^{21}$ Selain itu, segala perkara berkaitan hal ehwal agama Islam akan terus diletakkan di bawah bidang kuasa Perdana Menteri seperti pembinaan masjid dan perlantikan anggota pentadbiran masjid. ${ }^{22}$ Kemal juga bertindak melantik profesor-profesor Jerman berbangsa Yahudi sebagai salah satu program beliau untuk memodenkan sistem pendidikan Turki agar setanding dengan negara-negara Eropah yang lain. ${ }^{23}$ Kemal akan sentiasa diingati oleh umat Islam kerana terlibat secara langsung dalam meluluskan undang-undang untuk menyingkirkan khalifah terakhir kerajaan Turki Uthmaniyah iaitu Sultan Muhammad Wahiduddin pada 1 November 1922. ${ }^{2+}$ Meskipun Sultan Abdul Majid II (1922-1924) telah dilantik menjadi khalifah yang baru, baginda tidak lagi mempunyai kuasa memerintah Turki. ${ }^{25}$ Kemal dan pentadbirannya kemudian mengambil keputusan menghapuskan peranan dan kedudukan khalifah menerusi proses pengundian. ${ }^{26}$ Pada 3 Mac 1924, satu undangundang telah diluluskan oleh Majlis Perhimpunan untuk menghapuskan jawatan khalifah. ${ }^{27}$ Lanjutan daripada pengenalan undang-undang 
tersebut, Sultan Abdul Majid II dan kaum kerabatnya telah dihalau dari Turki. ${ }^{28}$ Tindakan Kemal menyingkirkan Sultan Abdul Majid II telah membawa kepada penghapusan sistem khalifah secara mutlak di Turki yang berusia hampir 640 tahun. $^{29}$

Meskipun kepatuhan dan ketaatan orang Melayu ketika itu masih tertumpu kepada raja-raja Melayu, namun minat orang Melayu terhadap peristiwa yang berlaku dalam Dunia Islam khususnya di Timur Tengah tidak pernah pudar. Orang Melayu bukan sahaja menunjukkan minat yang mendalam terhadap peristiwa kenaikan Kemal dan kejatuhan pemerintahan khalifah, bahkan juga menunjukkan minat yang tinggi terhadap pelbagai pembaharuan yang dilaksanakan oleh Kemal di bawah rancangan pemodenannya. Situasi ini bukan sahaja telah menarik minat akhbar dan majalah Melayu untuk membuat liputan yang meluas berkenaan isu-isu tersebut, bahkan telah menimbulkan polemik terbuka antara akhbar dan majalah Melayu tersebut khususnya berkenaan pelbagai pembaharuan yang dijalankan oleh Kemal sejak memimpin Turki menjadi sebuah republik.

\section{Polemik Dalam Akhbar Dan Majalah Melayu Berkenaan Pembaharuan Di Turki}

Syarikat percetakan akhbar dan majalah yang pertama di Turki telah ditubuhkan buat pertama kalinya di Istanbul pada tahun $1728,{ }^{30}$ Sejak itu, media cetak Turki telah berkembang dengan pesat. Ketika kenaikan Kemal, media cetak Turki hanya dibenarkan membuat liputan yang terhad berkenaan perkembangan yang sedang berlaku di Turki. Oleh yang demikian, akhbar dan majalah luar negara telah menyediakan gambaran yang lebih tepat dan jelas berkenaan pandangan umum orang Islam. ${ }^{31}$ Perkembangan di Turki telah mendapat liputan yang meluas oleh akhbar-akhbar di negara-negara Islam. Di Mesir misalnya, akhbar al-Ahram, al-Liwa' al-Misri dan al-Siyasa terus aktif menyiarkan pelbagai berita berkenaan peristiwa tersebut bermula dengan berita penghapusan institusi khalifah sejak minggu pertama bulan November 1922 (1-8 November 1922) ${ }^{32}$ Akhbar dan majalah Melayu juga tidak terkecuali daripada membincangkan pelbagai polemik yang berlaku akibat pembaharuan yang dijalankan oleh Kemal di Turki, bahkan telah menunjukkan kecenderungan dan minat yang ketara dalam menyiarkan pelbagai berita dan rencana berkaitan pembaharuan yang dijalankan oleh Kemal sekitar tahun 1920-an. Antara isu-isu yang sering menjadi polemik dalam akhbar dan majalah Melayu ialah berkenaan undang-undang yang mewajibkan pemakaian pakaian ala Barat, penggunaan tulisan Latin menggantikan tulisan Arab, terjemahan dan 
tafsiran al-Quran ke dalam bahasa Turki, pemansuhan pelbagai ajaran Islam yang dianggap lapuk dan rancangan emansipasi wanita Turki.

\section{a. Pakaian Barat Sebagai Lambang Ketamadunan}

Terdapat beberapa pembaharuan Kemal yang telah menimbulkan polemik terbuka antara akhbar dan majalah Melayu. Isu yang paling menimbulkan polemik terbuka dalam kalangan akhbar dan majalah Melayu adalah tindakan kerajaan Turki mengeluarkan peraturan yang mengharamkan pemakaian tarbus sebaliknya mewajibkan pemakaian topi ala Barat bagi golongan lelaki. ${ }^{33}$ Pemakaian serban juga tidak dibenarkan dan lelaki Turki dibenarkan memakai topi ala Barat sahaja. ${ }^{34}$ Selain itu, golongan ulama dan guru agama juga dipaksa memakai topi. ${ }^{35}$ Mana-mana golongan lelaki Turki yang masih memakai tarbus pula akan diseksa manakala golongan wanita yang memakai penutup muka ketika berjalan di tempat awam pula akan ditangkap. ${ }^{36}$ Bagi menambahkan lagi bekalan topi dan menggalakkan pemakaiannya, Menteri Perdagangan Turki juga telah melancarkan usaha untuk memperbanyakkan fabrik kain untuk pembuatan topi. ${ }^{37}$ Pasukan tentera Turki juga turut dibekalkan pakaian seragam baru beserta topi ala Barat. ${ }^{38}$

Akhbar dan majalah Melayu telah menunjukkan pandangan yang berbeza mengenai isu ini. Seruan Azhar misalnya cenderung kepada pandangan yang membenarkan pemakaian topi ala Barat. Pandangan tersebut adalah selaras dengan fatwa ulama al-Azhar yang mengharuskan pemakaian topi kerana pemakaiannya tidak berkait secara langsung dengan ajaran asas Islam. ${ }^{39}$ Namun begitu, pelaksanaan peraturan tersebut telah ditentang hebat oleh Pengasoh yang dianggap sebagai suara Kaum Tua. Bagi menyatakan bantahan terhadap peraturan tersebut, Pengasoh telah menyiarkan fatwa Mufti Masjid al-Haram, Sheikh Muhammad Ali al-Maliki Ibnu Sheikh Husin bahawa sesiapa yang memakai topi kerana berniat untuk mengagungkan dan menghormati budaya masyarakat Barat selain bertujuan untuk membesarkan syiar agama mereka, maka pemakainya boleh dianggap sebagai kafir. Sekiranya sesiapa memakai topi tersebut dengan tidak mempunyai apa-apa maksud iaitu sekadar menirunya sahaja, maka hukumnya adalah haram..$^{40}$ Mengulas isu tersebut, pengarang Pengasoh menyatakan bahawa:

Maka saya sangatlah hairan pada masa ini banyak anak-anak kita Melayu sangat suka memakai pakaian kafir, istimewa pula di sebelah tanah Johor iaitu suatu bandar dinamakan Batu Pahat, sangat mereka itu suka memakai topi hatta anak yang kecil itupun diajarkan memakai topi itu kerana mereka itu telah sangka sangat 
kebesaran memakai topi itu, lagipun orang-orang takut kepadanya. $^{41}$

Menurut Pengasoh lagi:

Hai saudara, tidakkah bagus tuan-tuan pakaian cara Melayu iaitu memakai songkok baldu serta baju teluk belanga, memakai seluar kemudian baharu memakai kain, maka pada pandangan saya sangatlah comelnya tambahan pun jikalau naik motosikal bertambahlah bagusnya...dan pula itu topi sangat hina, cubalah tuan-tuan iaitu sekiranya mengadap orang-orang putih waima masuk office tak dapat tidak disuruhnya buka itu topi iaitu menunjukkan hina. Jikalau sekiranya mulia kepada mereka itu janganlah disuruh buka kerana nampak kepala, setengah kepala mereka itu tidak berambut dan pula mana-mana yang bekas luka kelihatan pula hodoh rupanya. Dan jikalau kita memakai seperti pakaian kita tidaklah mereka itu menyuruh buka iaitu menunjukkan pakaian kita Melayu itu mulia, hendaklah tuantuan dan encik-encik pakai ini pengajaran kerana ulama menghukumkan dengan sebenarnya. ${ }^{42}$

Sebuah lagi akhbar berjudul Al-Hedayah juga turut menentang peraturan yang menghalang pemakaian tarbus sebaliknya menggalakkan pemakaian topi. ${ }^{43}$ Bahtra juga sependapat dengan $\mathrm{Al}$ Hedayah dalam isu ini dan menentang keras pelaksanaan undangundang yang mewajibkan pemakaian topi dan larangan memakai tarbus dalam kalangan lelaki Turki. Selain itu, Bahtra juga turut mempersoalkan tindakan kerajaan Turki menghukum rakyat Turki yang enggan memakai topi. ${ }^{44}$ Berdasarkan liputan yang dibuat oleh akhbar dan majalah Melayu, jelaslah bahawa hanya Seruan Azhar yang mengharuskan pemakaian topi ala Barat. Majoriti akhbar dan majalah Melayu seperti Pengasoh, Al-Hedayah dan Bahtra jelas menentang peraturan yang melarang pemakaian tarbus bagi lelaki serta larangan menutup muka bagi wanita.

\section{b. Penggunaan Tulisan Latin Menggantikan Tulisan Arab}

Satu lagi isu yang telah mewujudkan perbahasan yang hangat antara akhbar dan majalah Melayu adalah tindakan kerajaan Turki meluluskan undang-undang menukar penggunaan tulisan Arab kepada tulisan Rumi bagi bahasa Turki. Mulai bulan Disember 1928, semua akhbar, surat dan buku harus dicetak dalam tulisan Rumi. Bermula bulan Januari 1929 pula, semua surat-menyurat dan buku di pejabat kerajaan dan sekolah mestilah menggunakan tulisan Rumi dan tulisan Rumi juga akan diguna pakai di seluruh Turki mulai bulan Jun 1929. ${ }^{45}$ 
Lanjutan daripada pengenalan undang-undang tersebut, kerajaan Turki menguatkuasakan pula undang-undang yang menegah para peniaga daripada menjual barangan mereka menggunakan bahasa asing sebaliknya perlu menggunakan bahasa Turki dalam urusan jual beli mereka. ${ }^{46}$

Al-Ikhwan menganggap perubahan yang dijalankan sebenarnya tiada kena mengena dengan agama, sebaliknya bagi kemudahan dan kemajuan bangsa Turki. Tindakan tersebut juga tidak akan menghakis semangat kebangsaan Turki atau agama Islam. ${ }^{47}$ Saudara juga cenderung menyokong peraturan tersebut dan melaporkan bahawa penulispenulis Turki mula menulis dan menerbitkan buku dalam bahasa Turki yang dicetak dalam huruf Rumi ${ }^{48}$ Menurut Saudara lagi, Kemal juga telah menetapkan bahawa setiap rakyat Turki harus mampu menulis dalam tulisan Rumi dalam tempoh dua tahun kerana ketika itu, hanya 20 peratus sahaja rakyat Turki yang boleh membaca dan menulis bahasa Turki dalam tulisan Rumi ${ }^{49}$ Lanjutan daripada itu, Saudara juga turut mengalu-alukan tindakan kerajaan Turki yang menyediakan 12,000 guru untuk mengajar rakyat Turki berumur 46 tahun ke atas supaya mereka dapat menulis dan membaca bahasa Turki menggunakan tulisan Rumi. ${ }^{50}$

Sebuah lagi akhbar Melayu yang cenderung menyokong tindakan kerajaan Turki menggantikan tulisan Arab bagi memelihara 'keaslian' bahasa Turki ialah akhbar Al-Hedayah. Dalam keluaran November 1925, Al-Hedayah menegaskan bahawa bangsa Turki:

Sangat berpegang di atas bahasa mereka itu dan membersih (membuang) tiap-tiap perkataan asing yang termasuk di dalam bahasanya walaupun perkataan Arab. ${ }^{51}$

Berkenaan penggunaan bahasa Turki menggantikan bahasa asing dalam urusan jual-beli, Al-Hedayah menjelaskan bahawa:

Yang demikian itu kerana mengerti mereka itu akan hakikat yang sejati iaitu bahawa bahasa itu tanda perkauman. Mereka itu mengikut cara keeropahan akan tetapi mengekali mereka itu di atas bangsa dan bahasa mereka itu (Turki). Maka adakah kita mengerti akan hakikat ini dan kita menghinakan bahasa kita dan kita gunakan bahasa asing di dalam percakapan kita dan tulisantulisan kita? Adakah engkau ketahui bahawa bergantung dengan bahasa asing itu ialah suatu penyakit-penyakit hina, ertinya kita jadikan diri kita ekor bagi bangsa asing? ${ }^{52}$ 
Menurut Al-Hedayah lagi:

Akan tetapi tentang bahasa seperti percakapan dan di dalam karangan-karangan mereka itu tidaklah mereka itu buang, bahkan bersih dan ditapisi jika ada sebarang perkataan yang asing walaupun perkataan Arab yang telah menjadi bahasa mereka itu nescaya dibuang supaya kekal bahasa mereka itu sendiri. ${ }^{53}$

Al-Hedayah ternyata menyokong tindakan kerajaan Turki memelihara bahasa Turki dengan menyingkirkan unsur-unsur luar yang terdapat dalam bahasa Turki termasuklah bahasa Arab. Dalam hal ini, AlHedayah mungkin terlupa bahawa pengaruh Arab, khususnya bahasa Arab sendiri sebenarnya tidak dapat dipisahkan daripada kehidupan umat Islam kerana hampir keseluruhan ibadat umat Islam banyak menggunakan lafaz dalam bahasa Arab. Selain mengulas kesungguhan kerajaan Turki memelihara bahasa Turki dengan membuang unsurunsur asing, Al-Hedayah turut mengkritik sikap orang Melayu:

Bila tahu lebih kurang sahaja bahasa Inggeris itu digunakanlah selalu di dalam percakapan mereka itu walaupun bercakap mereka itu dengan sama sebangsa, seolah-olah bahasa sendiri Melayu ini hina. ${ }^{54}$

Walau bagaimanapun, pelaksanaan peraturan menggantikan tulisan Arab dengan tulisan Rumi menggunakan huruf Latin juga mendapat tentangan yang hebat daripada beberapa majalah Melayu. Pengasoh misalnya menentang keras penggantian tulisan tersebut dan beranggapan bahawa pengenalan peraturan tersebut, termasuklah pelbagai perubahan lain yang dijalankan oleh Kemal dan koncokonconya akhirnya menyebabkan, "cuma zahir perkataan 'Islam' sahaja yang mereka itu mengaku beragama dengan dia hari ini". ${ }^{5}$ Seruan Azhar juga kurang bersetuju dengan pelaksanaan peraturan tersebut. Menurut Seruan Azhar, penggunaan tulisan Rumi dibolehkan bagi mengembangkan ilmu pengetahuan tetapi tulisan Arab tidak wajar ditinggalkan sama sekali kerana tulisan Arab merupakan kunci kepada umat Islam untuk memahami maksud Al-Quran. ${ }^{56}$ Sebuah lagi majalah berjudul Dunia Melayu juga turut menentang peraturan tersebut. Menurut Dunia Melayu, pelaksanan peraturan tersebut akan merosakkan keimanan umat Islam. ${ }^{57}$ Bahtra juga turut menentang undang-undang yang membenarkan penggantian tulisan bahasa Turki daripada tulisan Arab kepada tulisan Latin. Menurut Bahtra, pelaksanaan undang-undang tersebut tidak sepatutnya dilaksanakan dengan keras dan para penentang undang-undang tersebut juga tidak 
sepatutnya diseksa dengan kejam. ${ }^{58}$ Dalam isu penggantian tulisan Arab dengan tulisan Latin dalam bahasa Turki, majoriti akhbar dan majalah Melayu seperti Pengasoh, Seruan Azhar, Dunia Melayu dan Bahtra lebih condong kepada pandangan yang menentang penggantian tulisan tersebut. Hanya majalah Al-Ikhwan, Saudara dan Al-Hedayah sahaja yang menyokong peraturan yang memperkenalkan tulisan Latin menggantikan tulisan Arab dalam bahasa Turki.

\section{c. Penterjemahan dan Pentafsiran Al-Quran Ke Dalam Bahasa Turki}

Kemal juga telah mengarahkan supaya Al-Quran dialih bahasa ke dalam bahasa Turki manakala pentafsirannya juga dibuat dalam bahasa Turki. Bagi melaksanakan peraturan tersebut, kerajaan Turki telah mewujudkan sebuah jawatankuasa yang terdiri daripada golongan ulama. Mana-mana bahagian yang telah siap akan dibawa kepada jawatankuasa tersebut yang akan memeriksa dan menyemaknya bagi memastikan setiap isi kandungannya sama dengan maksud asal dalam bahasa Arab. Mengulas isu tersebut, Al-Ikhwan jelas menyokong usaha kerajaan Turki dan menyatakan bahawa:

Demikianlah usaha dan bersungguh-sungguh kerajaan Turki
kepada Quran dan tafsirnya kerana hendak menyampaikan
pelajaran dan pengajarannya ke dalam kaumnya yang tiada
mengetahui melainkan bahasa Turki sahaja, iaitulah Turki yang
dituduh oleh orang pada masa ini telah menolak akan
agamanya. ${ }^{99}$

Al-Ikhwan jelas melahirkan nada kesal terhadap tuduhan bahawa Turki telah menolak Islam. Berdasarkan usaha penterjemahan dan pentafsiran tersebut yang dijalankan oleh kerajaan Turki, Al-Ikhwan berpendapat bahawa kerajaan Turki telah berusaha bersungguhsungguh untuk menyebarkan syiar Islam kepada rakyat Turki. Tindakan tersebut bukan sahaja dapat memberi peluang kepada rakyatnya yang hanya mengetahui bahasa Turki sahaja untuk memahami maksud al-Quran, bahkan dapat menggalakkan rakyat Turki memahami, menghayati dan mengamalkan isi kandungan alQuran dan tidak hanya membacanya sahaja.

Walau bagaimanapun, sebuah akhbar berjudul Bahtra mula mempertikaikan kesungguhan dan keikhlasan kerajaan Turki untuk membudayakan al-Quran dalam kehidupan rakyat Turki. Bahtra telah menyiarkan sebuah berita berkenaan tindakan Majlis Agama Turki yang telah mengeluarkan undang-undang melarang rakyat Turki membaca al-Quran di jalanan, di pintu-pintu masjid dan di tempat- 
tempat yang kurang sopan. Majlis tersebut menjelaskan bahawa alQuran diturunkan kepada manusia bukan untuk dilagu-lagukan tetapi untuk dijadikan panduan, peringatan, nasihat, petunjuk dan pengetahuan. Keraguan Bahtra tentang tujuan sebenar Majlis Agama Turki mengeluarkan undang-undang tersebut semakin terserlah apabila pengarangnya mencadangkan agar Majlis Agama di Semenanjung Tanah Melayu membawa isu tersebut untuk dibincangkan dalam mesyuarat majlis. ${ }^{60}$ Perbincangan isu penterjemahan dan pentafsiran Al-Quran ke dalam bahasa Turki sebenarnya kurang mendapat liputan yang meluas dalam dada-dada akhbar dan majalah Melayu berbanding isu-isu lain. Hanya Al-Ikhwan sahaja yang memberikan sokongan terhadap usaha pentafsiran dan penterjemahan tersebut malah bertindak mempertikaikan pihak yang meragui keikhlasan Kemal melaksanakan pembaharuan tersebut. Bahtra pula mempertikaikan tindakan kerajaan Turki mengharamkan rakyat Turki membaca Al-Quran di tempat awam dan meminta pihak berkuasa menyiasat kesahihan berita tersebut.

\section{d. Pemansuhan Ajaran Islam Yang Dianggap Lapuk}

Salah satu pembaharuan yang dijalankan oleh Kemal ialah pengenalan undang-undang perkahwinan sivil pada 4 Oktober 1926. Pelbagai peraturan baru yang bercanggah dengan ajaran Islam telah diperkenalkan termasuklah undang-undang perkahwinan sivil tersebut. Mana-mana pasangan yang mahu berkahwin hanya perlu datang sendiri ke Pejabat Pendaftaran dengan membawa dua orang saksi sahaja. Akad nikah yang merupakan salah satu syarat nikah juga tidak diwajibkan dan pasangan yang hendak membuat akad nikah boleh dijalankan di rumah mereka. ${ }^{61}$ Menurut ajaran Islam, wanita yang telah bercerai perlu menjalani idah sebanyak tiga kali haid dan wanita yang kematian suami pula perlu menjalani idah selama empat bulan sepuluh hari, ${ }^{62}$ namun begitu menurut peraturan baru tersebut, seorang wanita yang bercerai atau kematian suami hanya boleh berkahwin semula selepas 300 hari. ${ }^{63}$ Ajaran Islam juga mengharamkan seorang wanita berkahwin dengan lelaki bukan Islam tetapi peraturan baru tersebut membenarkan wanita berkahwin dengan mana-mana lelaki meskipun berlainan agama. ${ }^{64}$ Kerajaan Turki juga memperkenalkan satu peraturan baru yang menghalang lelaki berpoligami meskipun ajaran Islam membenarkannya. Selain itu, kuasa menjatuhkan talak ${ }^{65}$ juga tidak lagi khusus kepada lelaki sahaja kerana golongan wanita juga boleh memohon talak daripada hakim. ${ }^{66}$ Suatu peraturan baru berkenaan pembahagian harta pusaka antara lelaki dan wanita juga telah diperkenalkan. Meskipun ajaran Islam 
menentukan bahawa lelaki diberi dua bahagian harta pusaka berbanding wanita yang menerima satu bahagian sahaja, peraturan baru tersebut memberikan bahagian harta pusaka yang sama antara lelaki dan wanita. ${ }^{67}$

Salah sebuah majalah Melayu yang secara terang-terangan menyokong tindakan kerajaan Turki melaksanakan peraturan yang membenarkan wanita Islam berkahwin dengan lelaki berlainan agama, peraturan yang melarang lelaki berpoligami, peraturan yang membenarkan pelaksanaan undang-undang sivil Barat dan peraturan yang memberikan bahagian harta pusaka yang sama antara lelaki dan wanita ialah Al-Ikhwan. Menurut Al-Ikhwan:

Inilah dia segala perubahan di dalam Turki yang telah jadi baharu daripada mulai Mustafa Kemal mengedari kerajaan itu. Maka perubahan ini ialah perubahan yang elok yang bersetuju dengan masa ini pada pendapatan mereka itu, jika tidak begitu sekalipun pendapatan orang-orang lain. ${ }^{68}$

Pandangan Al-Ikhwan yang secara jelas menyokong tindakan kerajaan Turki yang menghapuskan ajaran Islam yang difikirkan 'lapuk' dan 'ketinggalan zaman' ini bertentangan dengan pandangan Pengasoh yang menentang keras peraturan yang membenarkan wanita Islam berkahwin dengan lelaki bukan Islam. Bagi mengukuhkan hujahnya, Pengasoh telah menyiarkan fatwa Mufti Mesir, Sheikh Abdul Rahman Qura' ah dan fatwa Sheikh al-Azhar, Sheikh Muhammad Abu al-Fadl. Fatwa tersebut menyatakan bahawa hukum seorang wanita mengahwini seorang lelaki bukan Islam adalah haram secara mutlak, tidak kira sama ada lelaki bukan Islam itu adalah seorang ahli kitab ${ }^{69}$ ataupun penyembah berhala. ${ }^{70}$ Pengasoh juga turut menentang paraturan yang memberikan bahagian harta pusaka antara lelaki dan wanita yang diperkenalkan oleh kerajaan Turki. Berdasarkan fatwa Mufti Mesir, Sheikh Abdul Rahman Qura'ah dan Sheikh al-Azhar, Sheikh Muhammad Abu al-Fadl, hikmah dilebihkan bahagian harta pusaka lelaki berbanding wanita adalah berdasarkan dalil al-Quran yang menyatakan bahawa lelaki bertanggungjawab untuk melindungi dan memelihara kaum wanita. ${ }^{71}$

Kerajaan Turki telah bertindak lebih agresif apabila membatalkan Islam sebagai agama rasmi Turki malah telah menggugurkan nama Allah dalam upacara sumpah. Segala bab dan bahagian di dalam buku undang-undang Turki berkenaan Islam juga telah dipadamkan. ${ }^{72} \mathrm{Al}$ Ikhwan yang telah menyiarkan berita tersebut mengambil sikap berdiam diri dan tidak memberikan sebarang ulasan dan pendapat. Sikap Al-Ikhwan yang berkecuali dalam isu tersebut kemungkinan besar 
disebabkan pendiriannya yang selama ini menyokong kuat pembaharuan yang dijalankan oleh Kemal, namun pembaharuan yang dijalankan oleh Kemal kali ini agak kontroversi dan secara terangterangan menolak Islam.

Sebuah majalah Melayu yang diterbitkan oleh pelajar-pelajar Melayu di Kaherah iaitu Pilehan Timoer pula menentang keras tindakan kerajaan Turki menggugurkan Islam sebagai agama rasmi Turki sebagaimana yang terkandung dalam undang-undang kerajaan Turki sebelum ini yang menyatakan bahawa agama kerajaan Turki ialah Islam dan syariat Islam wajib dilindungi dan dilaksanakan oleh kerajaan Turki. Pilehan Timoer juga turut menentang peraturan baru kerajaan Turki yang menggugurkan lafaz "Demi Allah" dalam upacara sumpah, sebaliknya ditukar kepada lafaz "Demi Kebangsaan dan Kemuliaan Turki". ${ }^{73}$ Mengulas isu tersebut, Pilehan Timoer menjelaskan bahawa:

Inilah khabar dari Turki yang selama ini kemenangannya tersebab kerana darah Islam dan selama ini satu kerajaan yang dikatakan kerajaan Islam, kemudian dikatakan oleh Mustafa Kemal dan Menteri Pengadilannya bahawa Republik Turki memakai asas tiada beragama apa jua lagi. ${ }^{74}$

Kerajaan Turki juga bertindak lebih jauh apabila meluluskan undangundang bagi memansuhkan kewujudan Mahkamah Syariah dan undang-undang syariah dan digantikan dengan undang-undang sivil dan jenayah berdasarkan undang-undang Itali, Perancis dan Switzerland. ${ }^{75}$ Isu penggantian undang-undang tersebut telah disokong oleh Al-Ikhwan yang telah mengambil pendekatan yang agak kontroversi berbanding akhbar dan majalah Melayu yang lain. Menurut Al-Ikhwan, perubahan yang dijalankan adalah sesuai dengan perubahan zaman berdasarkan pendapat sesetengah pihak yang menyokong pembaharuan tersebut. ${ }^{76}$

Pilehan Timoer yang menentang penggantian undang-undang syariah dengan undang-undang Barat yang dilaksanakan oleh kerajaan Turki mendakwa bahawa undang-undang sivil yang digunakan oleh kerajaan Turki sekarang kebanyakannya diambil dari undang-undang kerajaan Switzerland. Undang-undang tersebut pula banyak yang dikutip daripada undang-undang yang digunakan kerajaan Greek dan Rom suatu ketika dahulu. Menurut Pilehan Timoer lagi, undang-undang tersebut juga, "dipenuhi oleh jiwa agama Masihi (Kristian)" ${ }^{77}$ Pengasoh juga turut menentang penggunaan undang-undang Barat bagi menggantikan undang-undang Syariah yang dikuatkuasakan di Turki 
ketika itu. Menurut Pengasoh, kerajaan Turki melaksanakan peraturan tersebut atas alasan:

Supaya ada mereka itu bersatu acuan dengan republik Eropah maka undang-undang negeri Swiss [Switzerland] yang Majlis Negeri Turki menerima dengan sebulat-bulatnya, dari awal hingga akhirnya di dalam tepuk tangan yang deras pada suatu mesyuarat sahaja itu, sesungguhnya mereka itu memecahkan dengan dia segala belenggu kehinaan yang mereka itu terbelenggu dengan dia. ${ }^{78}$

Pada tahun 1928, kerajaan Turki di bawah pimpinan Kemal juga telah mencadangkan penubuhan sebuah jawatankuasa bagi mengkaji semula peraturan untuk menunaikan solat fardhu. Menurut Al-Ikhwan, jawatankuasa tersebut:

Telah memikirkan hendak mengubah peraturan sembahyang fardhu ini dengan peraturan Eropah juga iaitu memakai bunyibunyian dan sebagainya, tidak ada sujud, rukuk lagi bagaimana yang diwajibkan. ${ }^{79}$

Jawatankuasa tersebut jelas mahu mengubah cara menunaikan solat fardhu mengikut amalan penganut Kristian. Menurut ajaran Kristian, upacara sembahyang yang dilaksanakan di gereja akan disertai dengan alunan pelbagai bunyi muzik. Loceng juga akan dibunyikan bagi menandakan bahawa upacara sembahyang akan dimulakan. ${ }^{80}$ Meskipun Al-Ikhwan menyatakan bahawa cadangan tersebut akhirnya terpaksa dibatalkan kerana mendapat tentangan yang hebat daripada rakyat Turki selepas disiarkan di dalam akhbar dan majalah, ${ }^{81}$ namun cubaan tersebut menggambarkan tindakan halus Kemal dan pengikutnya dalam mensekularkan Turki.

Al-Ikhwan juga melaporkan tindakan kerajaan Turki yang telah menguatkuasakan peraturan yang mewajibkan khatib membaca khutbah Jumaat dalam bahasa Turki sahaja. ${ }^{82}$ Selain itu, seseorang itu tidak dibenarkan untuk mengajar atau mengaku bahawa dirinya seorang ulama melainkan setelah diperiksa dan diberikan kebenaran oleh kerajaan Turki. ${ }^{83}$ Kebencian kerajaan Turki terhadap institusi khalifah juga dapat dilihat dalam kes seorang khatib di Turki yang pernah ditangkap dan disoal siasat kerana mendoakan kesejahteraan khalifah dalam khutbahnya ${ }^{84}$ Menurut Seruan Azhar, usaha untuk mensekularkan Turki semakin terserlah apabila Kemal memerintahkan supaya sebuah patung dan gambar dirinya didirikan sempena majlis keramaian yang akan disambut oleh rakyat Turki. ${ }^{85}$ 
Saudara pula pernah menyiarkan berita berkenaan tindakan kerajaan Turki yang telah meluluskan satu peraturan baru berkenaan sambutan perayaan Islam. Kerajaan Turki dilihat cuba menghapuskan perayaan Maulidul Rasul yang biasa disambut oleh umat Islam sebelum ini. Alasan untuk memupuk semangat kebangsaan dalam kalangan rakyat Turki telah digunakan oleh kerajaan Turki untuk menggugurkan perayaan Maulidul Rasul tersebut dan digantikan dengan sambutan Hari Persatuan Kebangsaan Turki pada 28 Ogos, Hari Pembentukan Republik Turki pada 30 Ogos dan Hari Kemerdekaan Turki yang berlangsung pada 31 Ogos.$^{86}$ Isu pemansuhan ajaran Islam yang dianggap lapuk merupakan antara isu yang mendapat liputan yang meluas dalam kalangan akhbar dan majalah Melayu. Secara umumnya, majoriti akhbar dan majalah Melayu seperti Pengasoh, Seruan Azhar dan Pilehan Timoer menentang keras tindakan kerajaan Turki pimpinan Kemal yang bertindak menghapuskan pelbagai ajaran Islam yang dianggap lapuk dan kolot. Hanya Al-Ikhwan sahaja yang cenderung menyokong usaha kerajaan Turki untuk menghapuskan pelbagai ajaran Islam yang dianggap kolot dan ketinggalan zaman sebagai sebahagian daripada rancangan ke arah mewujudkan sebuah Republik Turki yang moden.

\section{e. Emansipasi Wanita Turki}

Kemal juga telah memperjuangkan isu emansipasi wanita dengan cukup lantang. ${ }^{87}$ Kerajaan Turki di bawah pimpinan Kemal misalnya sudah lama merancang untuk memberi hak yang sama kepada golongan wanita dalam pilihan raya dan pemerintahan Turki. Rancangan emansipasi wanita Turki juga dilihat telah mencapai matlamatnya apabila wanita Turki sering digambarkan menikmati kebebasan hidup yang lebih baik. Di Istanbul, wanita Turki bukan sahaja bebas memilih pasangan hidup, bahkan mendapat peluang yang lebih baik untuk menyambung pengajian peringkat tinggi di Eropah dan Amerika selain mendapat peluang pekerjaan yang lebih baik termasuklah menjadi peguam. Malah, terdapat wanita Turki yang menjadi kerani dan penulis di pejabat. Keadaan ini jelas berbeza dengan wanita Sham kerana mereka baru sahaja diberi jawatan sebagai guru sekolah rendah dan terdapat hanya enam orang pelajar perempuan sahaja di sekolah perubatan di Damsyiq. Keengganan kerajaan menyediakan pendidikan untuk wanita menyebabkan wanita Syam terpaksa merancang pembinaan sekolah perempuan yang menyediakan pelajaran seperti perusahaan dan pertukangan. ${ }^{88}$

Beberapa akhbar dan majalah Melayu juga jelas menyokong pelbagai rancangan emansipasi yang dilaksanakan oleh kerajaan Turki dalam rangka untuk memajukan wanita Turki dalam segenap aspek 
kehidupan. Al-Ikhwan misalnya mengalu-alukan tindakan kerajaan Turki menganjurkan pertandingan nyanyian untuk golongan wanita yang disertai oleh wanita daripada seluruh Turki termasuk daripada golongan bangsawan dan golongan ternama. Pertandingan tersebut telah dimenangi oleh Sayyidah Khadadad Syakir Hanim yang mendapat gelaran "Raja Suara Di Dalam Turki". Mengulas isu tersebut, Al-Ikhwan menjelaskan bahawa:

Bermula adalah perkara nyanyi dan lagu ini ialah suatu daripada perkara-perkara yang dijadikan oleh bangsa-bangsa Eropah bahagian yang besar juga bagi memajukan dia di dalam perhimpunan kaumnya, kerana di dalam kandungan lagu dan nyanyi syair mereka itu boleh memberi beberapa banyak kebajikan kepada pendengarnya dengan hati yang gembira di dalam tiaptiap perkara yang memberi kebajikan atau menolakkan kejahatan. ${ }^{89}$

Al-Ikhwan juga menyokong kejayaan wanita Turki yang berjaya diemansipasikan hasil rancangan pemodenan yang diperkenalkan oleh Kemal. Dalam keluaran 16 Mei 1927, Al-Ikhwan menyiarkan berita kejayaan seorang wanita Turki bernama Hasrah Hanim yang berjaya lulus dalam pengajian untuk menjadi peguam. Selain tu, gambar beliau yang tidak memakai tudung juga turut dipaparkan. ${ }^{90}$ Dalam keluaran 16 Jun 1927, Al-Ikhwan bertindak menyiarkan gambar seorang lagi wanita Turki bernama Saimi Mahmud yang menuntut dalam bidang kedoktoran di sebuah kolej perubatan di Constantinople (Istanbul) dalam keadaan memakai penutup kepala ala Barat. Dalam keluaran yang sama, turut dipaparkan gambar wanita Turki yang memakai penutup kepala ala Barat yang mula diperkenalkan sejak zaman kebebasan wanita Turki. ${ }^{91}$ Di samping menyokong pakaian ala Barat yang mula dipakai oleh wanita Islam, Al-Ikhwan juga menyokong fesyen rambut pendek yang menjadi trend wanita Barat ketika itu sehingga terdapat wanita Melayu yang turut meniru fesyen tersebut. Menurut Al-Ikhwan:

Tiadalah syak lagi bahawa menggunting rambut perempuanperempuan itu telah menyenangkan mereka itu membersihkan dia setiap-tiap masa, kerana perempuan-perempuan yang panjang rambut itu sentiasa mereka itu mendapat kepayahan membasuh dan mengeringkan serta menyikat akan dia sebelum mereka itu keluar pagi. Maka sekarang dengan kerana telah digunting ini hilanglah segala kepayahan itu. ${ }^{92}$

Kebebasan wanita Turki yang semakin jelas dan ketara sejak rancangan pemodenan yang diperkenalkan oleh Kemal bagi merealisasikan 
matlamat memperjuangkan emansipasi wanita juga telah ditentang hebat oleh Bahtra. Menurut Bahtra, tindakan Kemal yang memperkenalkan pelbagai peraturan untuk merealisasikan perjuangan emansipasi wanita Turki termasuklah membuang penutup muka tidak sepatutunya dilaksanakan. ${ }^{93}$ Pengasoh juga sependapat dengan Bahtra yang menentang rancangan emansipasi wanita Turki tajaan Kemal yang dianggap telah melampaui batas. Lanjutan daripada rancangan pemodenan tersebut bukan sahaja menggalakkan wanita Turki mendedahkan aurat mereka malah mendorong kepada pergaulan bebas antara lelaki dan wanita yang sebelum ini dikawal ketat. ${ }^{94}$ Menurut Pengasoh:

Sekarang kain nipis yang menutup muka perempuan-perempuan Turki dan hijab di antara mereka itu dengan laki-laki itu, tiada bekas lagi maka berubahlah penghidupan perkumpulan itu dari satu ke satu hal dengan sebab termasuk perempuan-perempuan bercampur di dalamnya. Inilah tanda tamadun Turki baharu itu. ${ }^{95}$

Sebuah lagi majalah berjudul Semangat Islam juga pernah menyiarkan rencana berkenaan seorang wanita Turki yang begitu lantang memperjuangkan emansipasi wanita Turki. Individu yang dimaksudkan ialah Halide Edib Hanim yang merupakan seorang pegawai tentera Turki yang kemudiannya dilantik sebagai Menteri Pelajaran Turki (1920-1922). Ketika tercetusnya Perang Dunia Pertama, beliau telah bertugas sebagai perisik kerajaan Turki. Beliau kemudiannya dilantik sebagai pegawai tentera Turki berpangkat Kolonel selepas bekerjasama dengan Kemal. Malah, beliau juga pernah memimpin angkatan tentera Turki menentang tentera Greek dan telah memperoleh kemenangan yang besar meskipun memiliki angkatan tentera yang lebih kecil serta kelengkapan yang serba kekurangan. Semenjak itu, beliau telah menjadi terkenal di seluruh Turki dan seluruh dunia sebagai seorang wanita yang mempunyai ketokohan dan keberanian yang tinggi. Beliau telah menyampaikan pidato bukan sahaja di Turki bahkan telah merantau ke seluruh dunia seperti Perancis, Britain dan Amerika untuk menyampaikan pidatonya berkenaan kesungguhan kerajaan Turki menjalankan pelbagai rancangan bagi memajukan golongan wanita Turki. Mengulas isu tersebut, Semangat Islam menjelaskan bahawa:

Bagaimanakah kaum ibu kita sekarang? Masih adakah lagi manusia yang mendakwa dirinya gutu atau pemimpin agama Islam yang melarang anak-anak perempuan itu dimasukkan ke dalam sekolah atau medan pelajaran? Belumkah habis waktunya 
lagi bagi kaum dan ketua-ketua agama kita? Buat memandang kaum ibu yang lemah itu sebagai barang permainan sahaja atau untuk melepaskan hawa nafsu yang di luar kemahuan agama Islam dan kemanusiaan. ${ }^{96}$

Meskipun Halide Edib Hanim pernah digelar "pahlawan kaum ibu" oleh rakyat Turki dan digambarkan sebagai wanita yang telah menikmati kebebasan dan mencapai kejayaan yang gemilang dalam kariernya apabila pernah menjadi seorang pegawai tentera Turki dan dilantik menjawat jawatan Menteri Pelajaran, namun beliau digambarkan tidak berpuas hati dengan tindakan kerajaan Turki mewajibkan pemakaian topi ke atas rakyat Turki. Pilehan Timoer melaporkan bahawa beliau dan suaminya, Dr. Adnan bertindak melarikan diri dari Ankara kerana tidak bersetuju dengan dasar kerajaan Turki yang bertindak menyeksa dan membunuh rakyat Turki yang tidak mahu mematuhi peraturan yang mewajibkan pemakaian topi. ${ }^{97}$ Seperti isu lain berkenaan rancangan pembaharuan Kemal, isu berkenaan emansipasi wanita Turki juga mengundang perbezaan pandangan dalam kalangan akhbar dan majalah Melayu. Dalam hal ini, Al-Ikhwan muncul sebagai penyokong kuat rancangan pembaharuan Kemal dalam isu emansipasi wanita Turki. Pandangan Al-Ikhwan ini ditentang hebat oleh Pengasoh dan Bahtra yang berpendapat bahawa emansipasi wanita Turki lebih banyak membawa kesan yang negatif kepada rakyat Turki khususnya golongan wanita kerana bukan sahaja menggalakkan pendedahan aurat tetapi juga membawa kepada pergaulan bebas antara lelaki dan wanita Turki.

\section{Reaksi Terhadap Rancangan Pembaharuan Kemal}

Beberapa akhbar dan majalah juga jelas menyokong penuh pembaharuan Kemal. Kesungguhan Al-Ikhwan menyokong perjuangan Kemal begitu nyata apabila majalah tersebut telah menyiarkan berita kejayaan Kemal dipilih semula secara sebulat suara sebagai Presiden Republik Turki pada bulan Oktober $1927 .{ }^{98}$ Al-Ikhwan juga telah menyiarkan sebuah rencana berkaitan usaha seorang penulis Perancis yang telah menerbitkan sebuah buku berkenaan kemajuan bangsa Turki di bawah kepimpinan Kemal. Penerbitan buku tersebut juga telah meninggalkan kesan yang mendalam kepada khalayak pembacanya sehingga mendorong seorang hartawan Perancis untuk meminjamkan sejumlah wang kepada ker ajaan Turki bagi memajukan lagi Turki selepas membaca buku tersebut. ${ }^{99}$ Kaum Muda juga sangat menyokong pembaharuan Kemal. Akhbar Saudara yang mewakili suara Kaum Muda menganggap Kemal ibarat Imam Mahdi yang telah dibangkitkan oleh Allah kerana berjaya memimpin gerakan Turki 
Muda untuk merampas semula Turki daripada pihak musah seterusnya membangunkan Turki menjadi sebuah negara yang maju dalam keadaan negara-negara Islam yang lain masih lagi mundur. ${ }^{100}$

Sokongan yang tidak berbelah-bahagi kepada kepimpinan dan kejayaan Kemal membangunkan Turki menyebabkan Al-Ikhwan mempertikaikan dakwaan beberapa akhbar yang melaporkan bahawa Kemal telah jatuh sakit. Menurut Al-Ikhwan, Kemal sebenarnya sentiasa sihat bagi menjalankan tugasnya setiap hari. ${ }^{101}$ Majalah Malaya juga telah menafikan laporan akhbar di Turki yang mendakwa bahawa Kemal telah mencampakkan salinan Al-Quran. Menurut majalah Malaya, dakwaan tersebut merupakan satu tuduhan yang tidak berasas dan hanya bertujuan untuk memburuk-burukkan kepimpinan beliau. ${ }^{102}$ Bagi memberi amaran kepada penentang pembaharuan Kemal pula, akhbar Saudara telah melaporkan bahawa sebuah pakatan sulit yang ditubuhkan oleh rakyat Turki bertujuan untuk mencederakan Kemal telah ditangkap di Istanbul dan sebahagian ahlinya telah dilepaskan manakala sebahagian lagi masih lagi ditahan. ${ }^{103}$

Sekiranya diteliti pada penyiaran berita berkenaan rancangan pemodenan Kemal, ternyata Al-Ikhwan lebih cenderung menyokong apa sahaja pembaharuan yang diperkenalkan oleh Kemal daripada bersikap menentang terhadapnya. ${ }^{104}$ Dalam banyak keadaan, Al-Ikhwan sering membenarkan segala tindakan Kemal secara membuta-tuli dan tidak lagi mampu menilai secara rasional segala tindakan dan kesan akibat rancangan pemodenan Kemal. Kelantangan Al-Ikhwan menyokong segala rancangan pembaharuan yang dijalankan oleh Kemal juga telah mencetuskan perbalahan dan perselisihan dengan beberapa majalah lain.

Sikap majalah Pengasoh yang memperlihatkan kecenderungan untuk menentang rancangan pemodenan Kemal misalnya telah menimbulkan konflik terbuka antara Pengasoh dengan Al-Ikhwan. Konflik mula timbul apabila kerajaan Kelantan di bawah bidang kuasa Majlis Agama Islam dan Adat Istiadat Kelantan ${ }^{105}$ bertindak menghalang edaran majalah Al-Ikhwan dan akhbar Saudara di Kelantan. Tindakan tersebut telah menimbulkan rasa tidak puas hati kepada Al-Ikhwan. Lanjutan daripada perselisihan tersebut, pengarang AlIkhwan mengkritik penerbitan Pengasoh dan menggambarkan isi kandungannya, “...semakin tirus umpama tirus ekor daripada kepala". ${ }^{106}$ Kemuncak kepada persengketaan ini adalah keengganan Al-Ikhwan untuk mengkafirkan rakyat Turki kerana pembaharuanpembaharuan yang dijalankan oleh Kemal walaupun telah dicabar oleh Pengasoh. ${ }^{107}$ Tindakan tersebut telah menyemarakkan lagi api perselisihan yang sudah sedia wujud antara kedua-dua majalah sejak sekian lama. 
Antara penulis yang cenderung menyokong rancangan pemodenan Kemal ialah Sheikh Tahir Jalaluddin. Beliau yang mewakili pemikiran orang Melayu yang progresif dan reformis pada waktu itu secara terbuka menyatakan sokongannya terhadap usaha pemodenan yang dilaksanakan oleh Kemal. ${ }^{108}$ Sheikh Tahir juga memberi amaran bahawa angin perubahan yang kini sedang melanda Dunia Islam yang bermula di Turki akan menjadi cukup kuat dan akhirnya ulama-ulama Kaum Tua yang menjadi penghalang kepada kemajuan dan penyebab kemunduran orang Melayu akan menerima nasib yang sama seperti ulama di Turki, iaitu apabila Kemal berjaya menggulingkan khalifah dan mengasaskan Republik Turki yang moden dan sekular. ${ }^{109}$

Ibrahim Mahmood juga cenderung menyokong rancangan pemodenan Kemal dan pelbagai usaha yang telah dijalankan oleh Kemal untuk mensekularkan Turki. Dalam tulisannya, Ibrahim secara terang-terangan menyokong perjuangan Kemal memodenkan Turki dan mempertahankan tindakannya mensekularkan Turki. Menurut beliau:

\begin{abstract}
Adapun pergerakan Mustafa Kemal pada mengadakan perubahan Turki itu tidaklah apa-apa kena mengena dengan masalah ugama, hanya ialah semata-mata pergerakan siasah dan maslahah hendak memerdekakan hamba rakyat dari kekuasaan mereka-mereka yang khianat dan yang tidak berperasaan kebangsaan atau tidak menghargakan bangsa dan tanah airnya dengan melakukan kezaliman atau belot ataupun memuaskan nafsu yang tamak halobanya. ${ }^{110}$
\end{abstract}

Menurut Ibrahim lagi:

Maka Turki berpendapatan tidak mustahak Turki bersandar atau bergantung kepada sesuatu kaum atau umat di dalam maslahah kebangsaan. Oleh itu, Turki tidak menghargakan bahasa Arab itu di dalam negeri dan di dalam pergaulannya. Pada hal ugamanya ialah ugama Islam yang suci jua. Maka tidaklah boleh disifatkan Turki membuang ugama dengan perbuatannya membuang bahasa Arab itu. ${ }^{111}$

Seorang lagi penulis yang turut menyokong perjuangan Kemal untuk mewujudkan sebuah negara Turki yang moden berasaskan prinsipprinsip sekular ialah Ahmad Ismail Al-Hikmah. Dalam tulisan beliau yang merupakan sebuah karya yang diterjemahkan ke dalam bahasa Melayu, Ahmad Ismail menegaskan bahawa kerajaan Turki bertindak menghapuskan institusi khalifah kerana: 
Ia telah lihat dan perhati dengan cermatnya bahawa ia tidak dapati suatu nas di dalam Al-Quran itu menyerukan pada mendirikan khilafah. Apa yang tersebut itu bahawa Al-Quran yang mulia itu menyerukan orang-orang Islam dengan taatkan Allah dan rasul-Nya dan orang-orang yang memerintahkan pekerjaan daripada mereka itu, di dalam ayat itu tidak dikehendaki bahawa orang yang memerintah pekerjaan itu wajib dan hendaklah ada mereka itu daripada khulafa' atau yang lain daripada khulafa'.112

Pada akhir tulisannya, Ahmad Ismail telah memuji usaha dan sumbangan Kemal:

\begin{abstract}
Sekarang fahamlah kita akan besar kejayaan dan jasa-jasa Ataturk kepada bangsanya dan di manakah ada bandingannya gundahgulana dan kesedihan bangsa Turki pada hari matinya itu? Maka memadalah menjadi dalil yang penuh dan cukup kemudian daripada khidmatnya, dan kebesaran kerugian oleh kehilangan dan kemuliaan pekerjaan yang telah ditunaikan itu adanya. ${ }^{113}$
\end{abstract}

Beberapa sarjana Islam turut mengkritik dan mempertikaikan rancangan pemodenan Kemal yang jelas meminggirkan Islam selain memperjuangkan unsur sekular. Seorang tokoh reformis yang terkenal di Timur Tengah iaitu Rashid Rida pada awalnya mengalu-alukan kejayaan yang dicapai oleh Turki dan kewibawaan Kemal kerana berjaya mempertahankan keutuhan politik Turki. Namun begitu, pendirian Rashid Rida mulai berubah selepas mendapati bahawa Kemal menyimpang terlalu jauh daripada prinsip dan ajaran Islam yang sebenar. Beliau berpendapat bahawa selaku pemimpin Turki, Kemal sepatutnya kembali kepada Syariah dan etika moral al-Quran yang tinggi sebagai landasan membangunkan Republik Turki yang baru dibentuk. Tindakan Kemal menterjemahkan al-Quran ke dalam bahasa Turki yang dianggap satu dosa besar akhirnya mengubah tanggapan Rashid Rida terhadap Kemal, iaitu daripada rasa hormat kepada perselisihan dan perseteruan. ${ }^{114}$ Rashid Rida juga beranggapan bahawa tindakan Kemal yang tidak mengambil kira perasaan umat Islam dalam melaksanakan rancangan pembaharuannya akan membawa kepada kekufuran, manakala Republik Turki yang berada di bawah pemerintahan Kemal pula bakal menuju ke arah kesesatan. ${ }^{115}$

Seorang tokoh pemikir Turki iaitu Badiuzzaman Said Nursi ${ }^{116}$ pula berpendapat bahawa kemerdekaan dan kemenangan yang dicapai oleh rakyat Turki dalam perjuangan menghalau British pada tahun 1922 sehingga berjaya menubuhkan Republik Turki pada tahun 1923 telah disalahgunakan kerana jihad agama ini telah diambil kesempatan 
oleh golongan tertentu untuk mendapat pengaruh dan nama. Beliau juga amat kesal dengan sikap pemerintah Turki di bawah pimpinan Kemal yang begitu prejudis terhadap agama, sehingga membawa kepada pemansuhan institusi khalifah pada tahun 1924 yang sebelum ini menjadi asas kekuatan dan keagungan Dunia Islam. ${ }^{117}$ Abdullah Azzam, seorang sarjana dan tokoh mujahid Islam pula beranggapan bahawa Kemal merupakan individu yang bertanggungjawab menghapuskan agama Islam dan menghancurkan Turki. Kemal juga bertindak menghapuskan agama Islam yang telah meninggikan bangsa Turki sehingga dapat menguasai dunia selama lima abad berturutturut serta bertanggungjawab menghancurkan tiang yang menumpang Daulah Uthmaniyah selama ini. Akibatnya, rakyat Turki mula berubah menjadi bangsa yang lemah dalam segala aspek kehidupan. ${ }^{118}$ Abdul Qadim Zallum berpendapat bahawa pihak British berjaya meruntuhkan institusi khalifah melalui peranan yang dimainkan oleh Kemal selaku tali barut mereka, setelah termeterainya Perjanjian Lausanne pada 24 Julai $1924 .{ }^{119}$ Seorang sejarawan Mesir iaitu Ahmad Syalabi pula berpendapat bahawa seluruh perubahan yang dilakukan oleh Kemal telah memutuskan Turki dengan masa lalunya iaitu Islam dan telah memutuskan Turki dengan saudara seagamanya di seluruh Dunia Islam. ${ }^{120}$

Sarjana Islam di Alam Melayu juga turut menetang keras rancangan pemodenan yang dilaksanakan oleh Kemal. Salah seorang ulama Alam Melayu yang menentang keras rancangan pembaharuan Kemal ialah Hamka. Beliau beranggapan bahawa Kemal adalah pelopor al-Ghazw al-Fikri (penjajahan fikiran) kerana bertanggungjawab memutuskan hubungan antara bangsa Turki dengan bangsa Arab dengan menukarkan lafaz azan dalam bahasa Arab kepada bahasa Turki dan menukarkan tulisan Arab kepada tulisan Latin bagi bahasa Turki. ${ }^{121}$ Seorang sarjana tempatan iaitu Mohd. Noor Haji Manuty juga turut sependapat dengan Hamka berkenaan dengan rancangan pemodenan Turki. Menurut Mohd. Noor, Kemal telah melakukan satu pembaharuan yang tidak rasional dan menyimpang jauh daripada garis panduan Islam yang sebenar. ${ }^{122}$

\section{Kesimpulan}

Sejak tahun 1920-an, akhbar dan majalah Melayu telah menunjukkan kecenderungan yang ketara dalam menyiarkan berita-berita berkenaan kenaikan Kemal Ataturk dan rancangan pemodenan yang dijalankannya sehingga menimbulkan polemik antara akhbar dan majalah Melayu. Kemal ternyata bijak menyembunyikan matlamat sebenarnya untuk mensekularkan Turki sebelum memimpin Turki dan 
hanya memperlihatkan matlamat sebenarnya setelah berkuasa. Polemik dalam akhbar dan majalah Melayu dalam beberapa isu pembaharuan yang dijalankan oleh Kemal menunjukkan bahawa pertelingkahan antara akhbar dan majalah yang menyokong pandangan Kaum Muda dengan akhbar dan majalah yang menyokong pandangan Kaum Tua terus berlangsung pada tahun 1920-an. Akhbar dan majalah Kaum Muda juga lebih banyak menyokong rancangan pembaharuan Kemal berbanding akhbar dan majalah Kaum Tua yang cenderung menentang pembaharuan beliau yang dianggap kontroversi. Antara majalah Melayu yang paling kuat menyokong kebanyakan rancangan pembaharuan yang dijalankan oleh Kemal ialah Al-Ikhwan yang merupakan suara Kaum Muda. Namun begitu, majoriti akhbar dan majalah Melayu menentang rancangan pemodenan yang dilaksanakan oleh Kemal.

Meskipun timbul polemik dalam akhbar dan majalah Melayu berkaitan beberapa isu, namun perkara ini tidak menghalang orang Melayu untuk terus mengikuti perkembangan tersebut dengan penuh minat. Hal ini menunjukkan bahawa orang Melayu begitu peka terhadap peristiwa yang sedang berlaku kepada saudara seagama mereka di Turki. Walaupun penyiaran berita berkenaan kejayaan Kemal menubuhkan Republik Turki belum membuktikan bahawa benih-benih semangat kebangsaan sudah mula subur dalam pemikiran orang Melayu, namun peristiwa penubuhan Republik Turki telah membuka mata orang Melayu bahawa umat Islam mampu membebaskan diri daripada kongkongan penjajah jika mereka bersatupadu. Meskipun rancangan pemodenan Kemal telah menimbulkan pelbagai kontroversi, namun perkara tersebut telah memberi inspirasi kepada orang Melayu untuk bangkit memajukan bangsa Melayu dalam segenap aspek. Dalam hal ini, sumbangan yang diberikan oleh akhbar dan majalah Melayu sebagai saluran utama dan penting bagi menyebarkan berita dan rencana tersebut amat besar sekali.

\section{Nota}

Lihat Pilehan Timoer, Jilid 1, Bil. 1, Oktober 1927, hlm. 9 dan Warta Malaya, 11 November 1938, hlm. 13, terlampir dalam MB 622/1938, 19 November 1938. Untuk maklumat lanjut tentang latar belakang dan biografi Kemal Ataturk, lihat H. C. Armstrong, Grey Wolf, Mustafa Kemal: An Intimate Study of A Dictator, London: A. Barker, 1932; Patrick B. Kinross, Ataturk: A Biography of Mustafa Kemal, Father of Modern Turkey, New York: William Morrowocco, 1964; Pahrol Mohamad Juoi, Kamal Ataturk: Ideologi dan Kesannya Ke Atas Rakyat Turki, Kuala Lumpur: Penerbit Hikmah, 1994; Matlob, Mustafa Kamal Ataturk: Bapa Turki Moden, Johor Bahru: Badan Bookstore, 1992. 
2 Dankwart A. Rustow, "Ataturk as a Founder of a State", Daedalus, Vol. 79, No. 3, 1968, hlm. 793.

3 Abdul Rauh Yaacob, "Hubungan Arabia Dengan British Pada Masa Perang Dunia Pertama, 1914-1918.", Jebat, Bil. 25, 1995, hlm. 97.

4 Feroz Ahmad, "Ottoman Perceptions of the Capitulations 1800-1914", Journal of Islamic Studies, Vol. 11, No. 1, 2000, hlm. 16.

$5 \quad$ Neracha, Jilid 4, No. 156, 14 Oktober 1914, hlm. 3.

6 Second Supplement to The London Gazette, 5 November 1914, hlm. 8997, terlampir dalam HCO 2031/1914, L. Harcourt kepada Pesuruhjaya Tinggi British, 20 November 1914. Di Tanah Melayu, berita peperangan antara pihak British dengan Daulah Uthmaniyah telah diedarkan ke seluruh Tanah Melayu termasuklah Negeri-Negeri Melayu Bersekutu, Johor dan Muar, Borneo Utara, Kelantan, Terengganu, Kedah dan Perlis. Lihat HC 1723/1914, "Notification Relating to the War with Turkey", Setiusaha Tanah Jajahan kepada Setiausaha Negeri-Negeri Melayu Bersekutu, Setiausaha Kerajaan Jesselton, Borneo Utara dan Penasihat British di Johor, Kelantan, Terengganu, Kedah dan Perlis, 6 November 1914.

$7 \quad$ Bahtra, Jilid 1, Bil. 50, 29 Julai 1932, hlm. 1.

8 Mehmet Maksudoðlu, Osmanlý Hitsory 1289-1922: Based on Osmanli Sources, Selangor: International Islamic University Malaysia, 1999, hlm. 241.

9 Noel Barber, The Sultans, New York: Simon and Schuster, 1973, hlm. 232-233. Akhbar dan majalah Melayu juga menunjukkan minat yang mendalam terhadap peristiwa penglibatan Turki dalam kancah Perang Dunia Pertama. Tunas Melayu misalnya telah menyiarkan pelbagai gambar pegawai tentera dan pasukan tentera Turki selain pelbagai kelengkapan dan senjata yang dimiliki oleh tentera Turki dalam peperangan tersebut. Untuk maklumat lanjut berkenaan gambargambar tersebut, lihat Tunas Melayu, Mei 1913, hlm. 9-12; Tunas Melayu, Jun 1913, hlm. 9, 12 \& 63; Tunas Melayu, Julai 1913, hlm. 79-80; Tunas Melayu, Ogos 1913, hlm. 93 \& 95; Tunas Melayu, September 1913, hlm. 109; Tunas Melayu, Oktober 1913, hlm. 122; Tunas Melayu, Disember 1913, hlm. 156; Tunas Melayu, Februari 1914, hlm. 28.

10 Alan Moorehead, Gallipoli, London: Hamish Hamilton Ltd, 1956, hlm. 359.

11 Dankwart A. Rustow, "The Army and the Founding of the Turkish Republic", World Politics, Vol. 11, No. 4, July 1959, hlm. 547.

12 Sultan Muhammad Al-Fatih (Mehmed II) berjaya menawan Constantinople pada 1453 lalu menukarkan namanya menjadi Istanbul. Sejak itu, Istanbul telah menjadi ibu kota kerajaan Turki Uthmaniyah. Untuk keterangan lanjut tentang Istanbul, lihat Halil Inalik, "Istanbul: An Islamic City", Journal of Islamic Studies, Vol. 1, 1990. hlm. 1-23.

13 Roderic H. Davison, Turkey: A Short History, Beverly: The Eothon Press, 1981, hlm. 277.

14 Bahtra, Jilid 1, Bil. 51, 9 Ogos 1932, hlm. 12. 
15 Geoffrey L. Lewis, Modern Turkey, London: Ernest Benn, 1974, hlm. 75.

16 Suna Kili, "Kemalism in Contemporary Turkey", International Political Science Review, Vol. 1, No. 3, 1980, hlm. 384. Bagi menggerakkan kemajuan Turki, Kemal juga turut memajukan sistem komunikasi Turki. Pada tahun 1927, Turki memiliki jalan keretapi sejauh 250 batu dan sistem telegraf yang meliputi lebih daripada 200 batu. Lihat Suara Malayu, Jilid 2, Bil. 82-83, 9-16 Ogos 1927, hlm. 1.

17 Nuri Eren, Turkey Today and Tomorrow: An Experiment in Westernization, London: Pall Mall Press, 1963, hlm. 100-102. Lihat juga Paul Stirling, "Religious Change in Republican Turkey", Middle East Journal, Vol. 12, 1958, hlm. 395-408.

18 Nilufer Gole, "Secularism and Islamism in Turkey: The Making of Elites and Counter-Elites", Middle East Journal, Vol. 51, Issue 1, 1997, hlm. 51.

19 Binnaz Toprak, Islam and Political Development in Turkey, Leiden: E. J. Brill, 1981, hlm. 45.

20 Untuk keterangan lanjut berkenaan penguatkuasaan Kod UndangUndang Sivil Switzerland di Turki, lihat Ruth A. Miller, "The Ottoman and the Islamic Substratum of Turkey's Civil Code", Journal of Islamic Studies, Vol. 11, No. 3, 2000, hlm. 335-361.

21 Gareth Jenkins, "Muslim Democrats in Turkey?", Survival, Vol. 45, Issue 1, 2003, hlm. 46-47.

22. Andrew Davison, "Turkey, a 'Secular' State? The Challenge of Description", The South Atlantic Quaterly, Vol. 102, No. 2-3, 2003, hlm. 339.

23 George S. Harris, Turkey: Coping with Crisis, Colorado: Westview Press, 1985, hlm. 180.

24 Geoffrey L. Lewis, Modern Turkey, hlm. 92. Tindakan Kemal menghapuskan pemerintahan khalifah berlawanan sama sekali dengan janji yang dibuat sebelumnya ketika menggembleng seluruh tenaga rakyat bagi menghalau tentera penceroboh dari bumi Turki. Pada tahun 1922, Kemal pernah memberi jaminan sebelum ini bahawa kedaulatan khalifah akan terus dipelihara sebagai lambang kepimpinan rohani umat Islam, walaupun institusi tersebut tidak memiliki kuasa politik. Menurut Kemal, beliau bertindak menamatkan pemerintahan khalifah kerana berpendapat bahawa khalifah telah mengkhianati negara kerana bersekongkol dengan kuasa asing yang menceroboh Turki. Lihat Mohammad Redzuan Othman \& Mashitah Sulaiman, Islam dan Politik di Turki, Petaling Jaya: Tradisi Ilmu Sdn. Bhd., 2005, hlm. 2. Tahun 1922 juga sangat penting dalam historiografi Turki dan Greece kerana menyaksikan termeterainya Perjanjian Lausanne yang telah menentukan semula sempadan Turki dan Greece moden sebagaimana pada hari ini. Untuk keterangan lanjut, lihat Damla Demirozu, "The Greek-Turkish Rapprochement of the Ankara Covention in Turkey", Journal of Islamic Studies, Vol. 19, No. 3, 2008, hlm. 309.

25 Reinhard Schulze, A Modern History of the Islamic World, New York: I.B. Tauris \& Co. Ltd., 2000, hlm. 65. 
26 Ermy Azziaty Rozali, 'Persepsi Dan Pengaruh Turki Uthmaniyah Ke Atas Masyarakat Melayu, 1876-1942', Tesis PhD., Universiti Malaya, 2009, hlm. 427.

27 Peter Mansfield, The Otttoman Empire and Its Successors, London: The Macmillan Press Ltd., 1973, hIm. 66.

28 Persahabatan, Jilid 1, Bil. 15, 23 November 1936, hlm. 11.

29 Stanford J. Shaw \& Ezel Kural Shaw, History of the Ottoman Empire and Modern Turkey, Vol. II, Cambridge: Cambridge University Press, 1985, hlm. 369.

30 Lihat Ahmed Emin, The Development of Modern Turkey as Measured by Its Press, New York: AMS Press, 1968, hlm. 14.

31 Richard Hattemer, "Ataturk and the Reforms in Turkey as Reflected in the Egyptian Press", Journal of Islamic Studies, Vol. 11, No. 1, 2000, hlm. 20.

32 Ibid., hlm. 23

33 Seruan Azhar, Jilid 1, No. 1, Oktober 1925, hlm. 19.

34 Al-Hedayah, November 1925, hIm. 170.

35 Al-lkhwan, Jilid 1, Bil. 10, 16 Jun 1927, hlm. 198.

36 Seruan Azhar, Jilid 2, No. 15, Disember 1926, hIm. 299

37 Seruan Azhar, Jilid 1, No. 4, Januari 1926, hlm. 79.

38 Seruan Azhar, Jilid 1, No. 1, Oktober 1925, hlm. 19.

39 Seruan Azhar, Jilid 1, No. 2, November 1925, hlm. 23-24. Seruan Azhar ternyata lebih sederhana dalam memberikan pandangan berkenaan pembaharuan Kemal. Meskipun tindakan kerajaan Turki menghapuskan institusi khalifah dan menyingkirkan keluarga Uthmaniyyah pada tahun 1924 masih meninggalkan kesan yang besar terhadap Dunia Islam, namun Seruan Azhar menegaskan bahawa rakyat Turki lebih bernasib baik kerana berada di bawah pemerintahan republik melihat kepada pelbagai pembangunan dan peraturan yang dijalankan. Lihat Seruan Azhar, Jilid 2, No. 23-24, Ogos-September 1927, hIm. $467-468$.

40 Pengasoh, Jilid 9, No. 204, 22 September 1926, hlm. 7.

41 Ibid., hlm. 8

42 Ibid.

43 Al-Hedayah, November 1925, hlm. 170. Tarbus yang dipakai oleh rakyat Turki dan menjadi simbol kedudukan seseorang dalam Daulah Uthmaniyah digelar fez. Untuk keterangan lanjut, lihat H. B. Sharabi, Government and Politics of the Middle East in the Twentieth Century, New York: D. Van Nostrand Company Inc., 1962, hIm. 42.

44 Bahtra, Jilid 1, Bil. 51, 9 Ogos 1932, hlm. 12

45 Saudara, Jilid 1, No. 7, 10 November 1928, hlm. 1.

46 Al-Hedayah, November 1925, hlm. 170.

47 Al-Ikhwan, Jilid 2, Bil. 9, 16 Mei 1928, hlm. 281-286

48 Saudara, Jilid 1, No. 3, 13 Oktober 1928, hlm. 2.

49 Saudara, Jilid 1, No. 4, 20 Oktober 1928, hlm. 1.

50 Saudara, Jilid 1, No. 5, 27 Oktober 1928, hlm. 2.

51 Al-Hedayah, November 1925, hlm. 170. 
52 Ibid.

53 Ibid.

$54 \quad$ Ibid.

55 Pengasoh, Jilid 8, No. 192, 28 Mac 1926, hlm. 7.

56 Seruan Azhar, Jilid 1, No. 6, Mac 1926, hlm. 110-113.

57 Dunia Melayu, 20 Februari 1929, hlm. 36.

58 Bahtra, Jilid 1, Bil. 51, 9 Ogos 1932, hlm. 12.

59 Al-Ikhwan, Jilid 1, Bil. 6, 16 Februari 1927, hlm. 123.

60 Bahtra, Jilid 1, Bil. 26, 22 April 1932, hlm. 4.

61 Al-Ikhwan, Jilid 1, Bil. 3, 16 November 1926, hlm. 57.

62 Muhammad Shidiq Hasan Khan, Ensiklopedia Hadis Sahih: Kumpulan Hadis Tentang Wanita, (terj.), Jakarta Selatan: Penerbit Hikmah, 2009, hlm. 228.

63 Ibid., hlm. 57-58.

64 Al-Ikhwan, Jilid 2, Bil. 9, 16 Mei 1928, hlm. 286.

65 Talak merupakan tindakan melepaskan ikatan perkahwinan dengan lafaz atau perkataan yang tertentu. Untuk keterangan lanjut, lihat Mat Saad Abd. Rahman, Undang-Undang Keluarga Islam: Aturan Perkahwinan Suatu Pendekatan Berdasarkan Amalan Semasa, Shah Alam: Penerbit Hizbi, 1993, hlm. 129.

66 Al-Ikhwan, Jilid 1, Bil. 10, 16 Jun 1927, hlm. 198.

67 Al-Ikhwan, Jilid 2, Bil. 9, 16 Mei 1928, hlm. 286.

68 Ibid.

69 Menurut majoriti ulama, ahli kitab merupakan penganut-penganut agama Yahudi dan Kristian dari dulu, kini dan selamanya. Lihat Maszlee Malik \& Hamidah Mat, Fikah Luar Negara: Mudah Praktik Islam Di Mana-Mana, Kuala Lumpur: PTS Millenia Sdn. Bhd., 2006, hlm. 108.

70 Pengasoh, Jilid 8, No. 192, 28 Mac 1926, hlm. 11-12.

${ }_{71}$ Ibid., hlm. 12. Ayat al-Quran yang dimaksudkan ialah ayat 34, surah an-Nisa'.

72 Al-Ikhwan, Jilid 2, Bil. 8, 16 April 1928, hlm. 245-246.

73 Pilehan Timoer, Jilid 1, Bil. 7, April 1928, hlm. 112.

74 Ibid,

75 Al-Ikhwan, Jilid 2, Bil. 9, 16 Mei 1928, hlm. 286.

76 Ibid

77 Pilehan Timoer, Jilid 1, Bil. 7, April 1928, hlm. 115.

78 Pengasoh, Jilid 8, No. 192, 28 Mac 1926, hlm. 8.

79 Al-Ikhwan, Jilid 2, Bil. 4, 16 Disember 1928, hlm. 124.

80 O.K. Rahmat S.H., Dari Adam Sampai Muhammad: Sebuah Kajian Mengenai Agama-Agama, Kota Bharu: Pustaka Aman Press, 1976, hlm. 455.

81 Al-Ikhwan, Jilid 2, Bil. 4, 16 Disember 1928, hlm. 125.

$82 \quad$ Al-Ikhwan, Jilid 1, Bil. 10, 16 Jun 1927, hlm. 198.

83 Ibid.

84 Seruan Azhar, Jilid 1, No. 7, April 1926, hlm. 139-140.

85 Ibid., hlm. 140.

86 Saudara, Jilid 1, No. 8, 17 November 1928, hlm. 1. 
87 Menurut Kamus Dewan, emansipasi bermaksud pemberian hak yang sama dalam hukum iaitu wanita mendapat hak yang sama dengan lelaki. Untuk maklumat lanjut, lihat Kamus Dewan, Edisi Keempat, Kuala Lumpur: Dewan Bahasa dan Pustaka, 2010, hlm. 386.

Kenaikan Kamal Di Turki: Reaksi Orang Melayu", dalam Farid Mat Zain (ed.), Daulah Uthmaniyah dan Alam Melayu: Detik Kejatuhan Khalifah Islamiyah di Turki 1924 dan Reaksi Orang Melayu, Shah Alam: Karisma Publications Sdn. Bhd., 2009, hlm. 210.

105 Untuk keterangan lanjut tentang Majlis Agama Islam dan Istiadat Melayu Kelantan, lihat William R. Roff, "The Origin and Early Years of the Majlis Ugama", dalam William R. Roff (ed.), Kelantan: Religion, Society and Politics in a Malay State, Kuala Lumpur: Oxford University Press, 1974, hlm. 101-152. Lihat juga tulisan Noraini Md. Zain, "Sejarah Penubuhan Majlis Agama Islam dan Adat Istiadat Melayu Kelantan", dalam Nik Mohamed Nik Mohd. Salleh (ed.), Warisan Kelantan VII, Kota Bharu: Perbadanan Muzium Negeri Kelantan, 1988, hlm. 60-69; Abdul Razak Mahmud, "Tujuh Puluh Lima Tahun Majlis Agama Islam dan Adat Istiadat Melayu Kelantan", dalam Nik Mohamed Nik Mohd. Salleh (ed.), Warisan Kelantan XI, Kota Bharu: Perbadanan Muzium Negeri Kelantan, 1992, hlm. 1-19.

106 Al-lkhwan, Jilid 3, Bil. 7, 16 Mac 1929, hlm. 215.

107 Ibid., hlm. 217.

10* HAMKA, Ajahku: Riwayat Hidup Dr. H. Abd. Karim Amrullah dan Perdjuangan Kaum Agama di Sumatera, Djakarta: Penerbit Djajamurni Djakarta, 1967, hlm. 124. 
109 Al-Ikhwan, Jilid 1, Bil. 3, 16 November 1926, hlm. 41.

110 Ibrahim Mahmood, Turki dan Tamadunnya, Pulau Pinang: The Merchantile Press, 1938, hlm. 69.

111 Ibid., hlm. 69-70.

112 Ahmad Ismail al-Hikmah, Turki Baharu, Penggal Yang Kedua: Tarikh Perubahan, Pergerakan-Pergerakan Kemajuan Turki dan Islah atau Perbinaan Baharu Sehingga Kematian Ataturk, Kota Bharu, Matbaah Al-Hikmah Kelantan, t.t., hlm. 14.

113 Ibid., hlm. 59.

114 Lihat E. I. J. Rosental, Islam in the Modern National State, Cambridge: Cambridge Unibversity Press, 1965, hlm. 75-76.

115 Berkes Niazi, The Development of Secularism in Turkey, Montreal: McGill University Press, 1964, hlm. 488.

116 Badiuzzaman Said Nursi (1877-1960) dilahirkan di perkampungan Nursi yang terletak di sebelah timur Turki. Beliau bukan sahaja terlibat dalam menubuhkan madarasah, menyertai parti politik dan menjadi penulis dalam akhbar dan majalah Turki, malah telah menghasilkan sebuah buku yang terkenal berjudul Rasa'il al-Nur. Said Nursi juga telah memimpin sebuah gerakan islah yang dikenali sebagai gerakan Nurcu. Perjuangannya untuk menegakkan semula syiar Islam di bumi Turki juga menyebabkan beliau telah dipenjarakan oleh pemerintah Turki. Untuk keterangan lanjut, lihat Zaki Saritoprak, "Islam and Politics in the Light of Said Nursi's Writings", Islam and ChristianMuslim Relations, Vol. 19, No. 1, 2008, hlm. 113-119; Serif Mardin, Religion and Social Change in Modern Turkey: The Case of Bediuzzaman Said Nursi, New York: State University of New York Press, 1963, hlm. 75-77; Sukran Vahide, Islam in Modern Turkey: An Intellectual Biography of Bediuzzaman Said Nursi, Albany: State University of New York Press, 2005, hlm. 3-32.

117 Mohamad Zaidin Mat, "Kejatuhan Khilafah dan Respons Badiuzzaman Said Nursi", dalam Farid Mat Zin (ed.), Daulah Uthmaniyah dan Alam Melayu, Shah Alam: Karisma Publications Sdn. Bhd., 2009, hlm. 129.

118 Abdullah Azzam, Turki Negara Dua Wajah: Pengkhianatan Ataturk Terhadap Dunia Islam (terj.), Kuala Lumpur: Alam Raya Enterprise, 2007, hlm. 57.

119 Abdul Qadim Zallum, Konspirasi Barat Meruntuhkan Khilafah Islamiyah, (terj.), Bangil, Jawa Timur: Penerbit Al-Izzah, 2001, hlm. 184-185.

120 Ahmad Syalabi, Sejarah dan Kebudayaan Islam: Imperium Turki Utsmani (terj.), Jakarta: Penerbit Kalam Mulia, 1988, hlm. 85.

121 HAMKA, Beberapa Tantangan Terhadap Umat Islam Dimasa Kini, Jakarta: Penerbit Bulan Bintang, 1970, hlm. 5-6.

122 Mohd. Noor Haji Manuty, "A Critical Analysis on Mustafa Kamal Ataturk's Reform: The Experience of Turkey", Islamiyyat, Jilid 4, 1982, hlm. 39. 